\title{
Trend of Research on Fireproof of Prestressed Concrete Structure
}

by

\author{
Masatomo YOSHIDA*
}

Key words:Prestressed concrete, Fireproof, Trend

\section{1 緒}

鉄筋コンクリート構造（以下、 RC と造と略）や鋼構 造（以下、S 造と略）などの耐火構造が火災時に倒壊な り，大きな被害を出して，問題となった事例は我が国で はまず見当たらない。しかし，プレストレストコンクリ 一ト（以下、 $\mathrm{PC}$ と略）構造は, $\mathrm{RC}$ 造や $\mathrm{S}$ 造と比較する と, 構造上特異な点を有しているため, $\mathrm{PC}$ 構造の耐火 性に対する疑念は残っている. PC 構造が RC 造の範疇に 入ると考えると, 建設省告示第 1399 号 ${ }^{1)}$ で耐火構造と して例示されていることとなる。一般に PC 構造は耐火 構造であるという認識があったため, また, PC 構造の 火災事例が我が国ではなかったために，その耐火性に関 する研究はさほど活発には行われてこなかったものと 考えられる。しかし，もし火災が一旦発生すると，PC 構造の耐火性能を疑問視する向きがある，最近は，西山 研究室 (京都大学) で活発に研究が行われている.

本編は，PC 構造の耐火性を明らかにし，火災時の耐 火性に警鐘を鳴らす意味合いで本テーマを取り上げた。 PC 構造の耐火性については, 日本材料学会 PC 部門委員 会 (委員長 : 中塚佶元大阪工業大学教授) でも取り組み が行われている。

ここでは, PC 構造の耐火性に関する研究動向を述べ るとともに, 今後の研究課題の発掘の一助としたいと考 えた。温故知新になぞらえ，今までに余り多くの研究は なされていないものの，判明している知見を整理し，未 解明な点を明らかにした。調查分野としては，建築・土 木，構造としては梁・床を対象とした。

過去の研究は, 大きく構造と耐火の両面からである. 構造面からの研究は, 坂静雄博士から端を発し，六車熙 博士，西山峰弘博士へと受け継がれ，PC 構造の立場で 耐火性について研究を行っている。その成果は，PC 設 計施工規準・同解説 ${ }^{2)}$ 等に反映されている. また，耐火 面からの研究は，川越邦雄博士から，齋藤光博士，上杉 英樹博士へと受け継がれ，耐火の立場で PC 構造の特性 について研究を行ってきた。

\section{2 現行法規・規準等による規定}

PC 構造の耐火性に関する規定類を調べてみると, 以 下のような内容である. 建築基準法 ${ }^{3)}$ 第 2 条の七の耐火 構造の規定には, PC 構造は含まれていない, 建設省告 示第 1399 号 ${ }^{1)}$ の例示仕様にも PC 構造としては厳密に は含まれていない。唯一, 性能評価機関の「試験・評価 業務方法書」4) で，鋼材温度（最高）の規定が設けられ

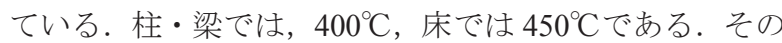
他, 規準・指針類としては, PC 設計施工規準・同解説 ${ }^{2)}$, 穴あき $\mathrm{PC}$ 板設計施工指針 ${ }^{5)}$ に耐火性能が示されている.

また, コンクリートかぶり厚さの推奨值が耐火 30 分 から 3 時間まで, JASS 5, PC 規準 ${ }^{2)}$, ACI (American Concrete Institute), FRS (Fire Research Station), FIP/CEB

( Fédération Internationale dela Précontrainte/Comité Européen du Béton) 推奨, PCI (Prestressed Concrete Institute）で定められている.

\section{3 一般的な PC 構造の耐火特性}

一般的に示されている PC 構造の耐火特性について概 括する.

\section{3・1 PC 鋼材の高温性状}

「構造材料の耐火性ガイドブック」 ${ }^{6)}$ には以下の内容 が示されている。

3・1・1 高温時強度 温度の上昇に伴い, $\mathrm{PC}$ 鋼材は 強度低下が見られ, 特に $300 \sim 350^{\circ} \mathrm{C}$ を超えると急激な低 下傾向が確認できる (図 1 参照).

3・1・2 加熱泠却後の常温時強度 （1） PC 鋼棒は， 温度が $500^{\circ} \mathrm{C}$ 程度から強度低下が見られる (図 2 参照).

(2) $\mathrm{PC}$ 鋼線は， $300^{\circ} \mathrm{C}$ 程度を超えるとその径にかか わらず低下傾向が見られる.

\section{$3 \cdot 2$ PC 構造部材の火災時の性状}

$\mathrm{PC}$ 構造部材の火災時の性状について, 「新版 建築防 火教材」 ${ }^{8)}$ より, PC 部分の内容を示す.

$\mathrm{PC}$ 部材は, RC 部材とは鋼材の高温性状が多少異なる ことと初期応力が導入されている点が異なるだけであ り，本質的には同じである.

$3 \cdot 2 \cdot 1$ 曲げ応カを受ける部材 $\mathrm{PC}$ 構造の場合は,

$\dagger$ 原稿受理 平成 25 年 8 月 12 日 Received Aug. 12, 2013 (c) 2014 The Society of Materials Science, Japan

* 正 会 員 大阪工業大学八幡工学実験場 †614-8289 八幡市美濃山一八谷, Yawata Eng. Lab. of O.I.T, Minoyam, Yawata, 614-8289 
ただ鉄筋の存在応力がはるかに多いため RC 造の場合よ りも低温で, クリープ現象が生じてプレストレスを失い, 部材の曲げ変形が急増する (図 3 参照).

3・2・2 コンクリートの爆裂 コンクリートの爆裂 現象は，とくに PC 構造に生ずる危険が大きいとされて いる，下記に示す条件の時，爆裂を生じやすいことが判 明している。

・コンクリートの含水率が大

・部材の厚さが薄い（5cm 以下）

・I 形はりの薄いウェッブ

・梁および柱の隅角部

・導入プレストレスカが大

・急激に加熱する

・而讨試験の初期

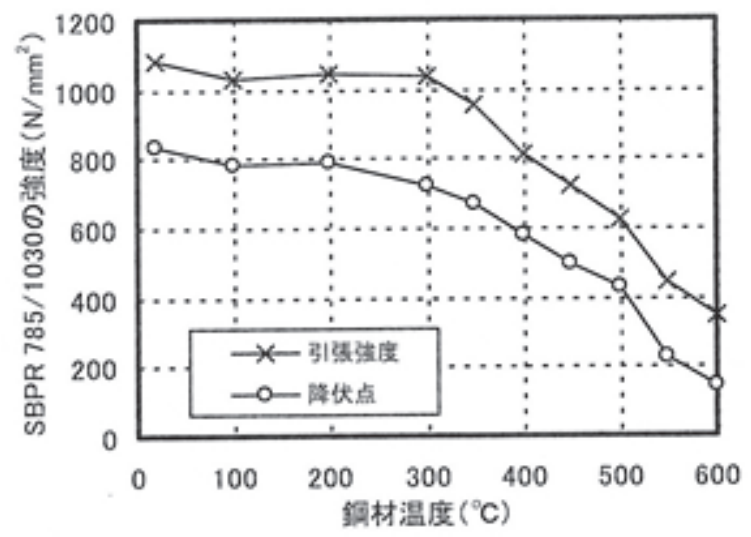

図 1 SBPR785/1030 の高温時強度 7

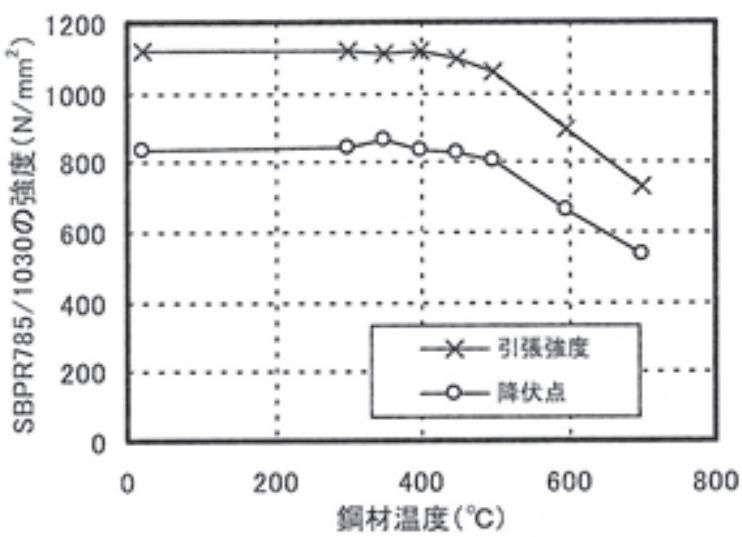

図 2 SBPR785/1030 の加熱泠却後の常温時強度 7)

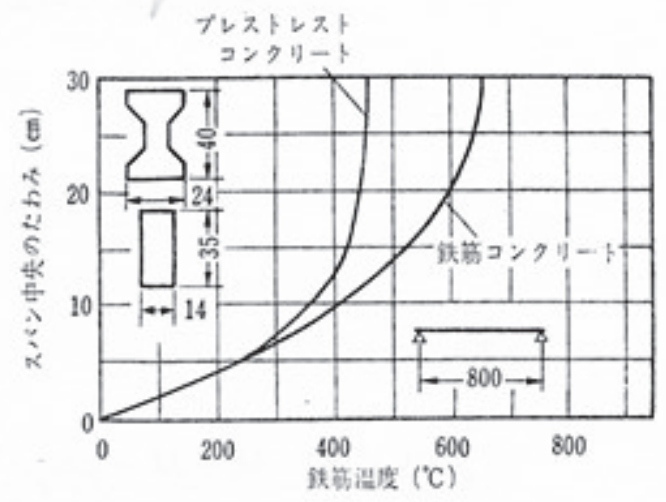

図 3 鉄筋温度とはりのたわみの関係 ${ }^{8)}$

\section{4 坂 : 六車の研究}

\section{$4 \cdot 1$ 坂の研究}

坂博士は海外の実験結果を紹介している ${ }^{9)}$.

4・1・1 イギリスの FRS の実験 1953 年に報告さ れたもので，BS（British Stanndards）に基づいて載荷加 熱実験を行った。その加熱試験は次の 2 種類である.

(1) 破壊まで加熱

（2）破壊が起こると予想される時間の半分加熱, 冷却 後強度試験を実施

試験体は $\mathrm{T}$ 型の梁（幹部の幅:約 6inch $(152 \mathrm{~mm})$ ) で あった。結果は以下の通りであった.

(a)かぶり 2.5inch (63.5mm) あれば，2 時間の耐火が可 能である。緊張材の温度が $400^{\circ} \mathrm{C}$ を超えなければ, 長時 間の耐火性がある。試験体の縮尺と耐火時間の関係を図 4 に示す。

(b)4 時間以上の耐火力を要求する場合，軽量モルタルな どの防火塗装が必要である.

(c)設計荷重, かぶりが等しければ, 矩形断面と I 形断面 とで耐火力の差はない.

(d)破壊は急激ではない. プレストレスが減少するにつれ てたわみが大きくなり，崩壊が来る前に危険性を予想で きる。

(e)崩壊に至る時間よりも早く加熱を止めた試験体は冷 却後支持能力の減退は少ない。しかし，永久たわみがあ り，いくらかのプレストレスの減少もある.

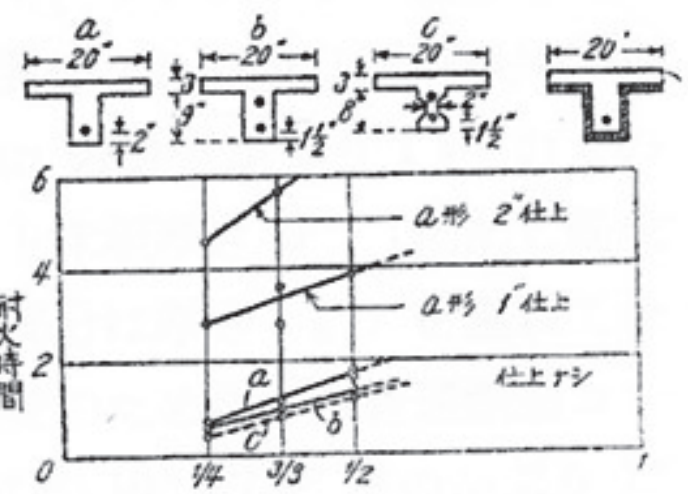

模形电摍尺

図 4 FRS の実験結果 ${ }^{9}$ 
4・1・2 G.Baar の実験 1950 年に報告されたもの で，試験体は実大ポストテンション PC 梁で，加熱は標 準ではない(図 5 参照)。結論として，火災の時に PC 梁 が完全に破壊されるとは考えられないが， RC 梁よりた わみが大きくなると考えられる.

4・1・3 L.A.Ashton の実験 1951 年に報告された もので，試験体は PC 床，プレテンション PC 梁である

(図 6 参照)。これらの耐火試験で火熱によるコンクリ 一トの破砕は起こっていないと報告されている.

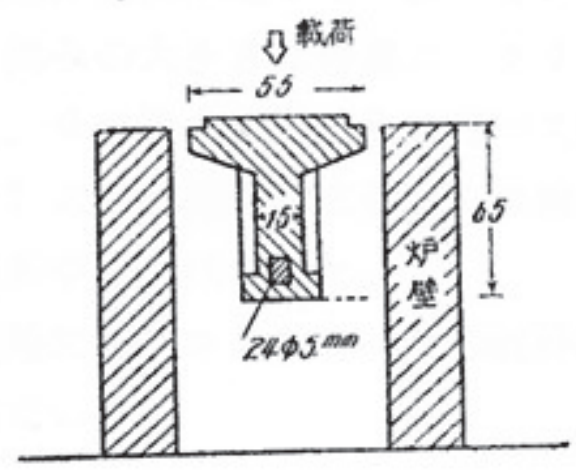

図 5 Baar の実験の試験体及び試験装置 ${ }^{9)}$ (寸法単位 $: \mathrm{cm}$ )

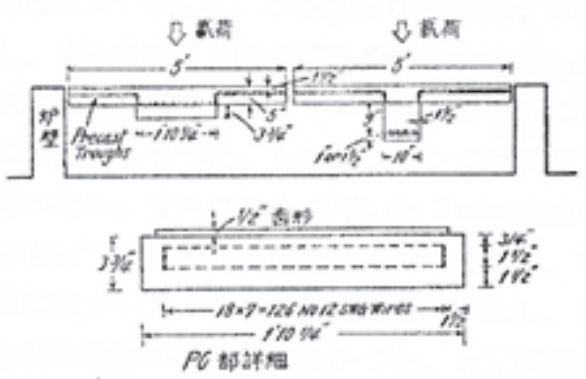

図 6 L. A. Ashton の実験の試験体及び試験装置 ${ }^{9)}$

\section{$4 \cdot 2$ 六車の研究}

六車博士は PC 構造の耐火性および火災事例について, 概括している ${ }^{10)}$

(1) PC 構造の耐火性

(a)従来，耐火力が極めて少ないと考えられていた.

(b)PC 部材の耐火性に関し RC 部材より慎重に取り扱う べき特殊事情としては以下の通りである.

(1)PC 鋼材は冷間引き抜きまたは熱処理により高度の強 加工が施されているため，温度の影響を受けやすい。

(2)火災によりプレストレスが失われる不安がある.

(3)ドイツ RC 委員会などの結論では，PC 鋼材温度が $400^{\circ} \mathrm{C}$ 以下であれば，問題とならないとしている.

(4) 2 時間耐火を目標として，最小かぶり厚さが $5 \mathrm{~cm}$ と定 められている22.

(5)PC 鋼材のかぶり厚さを充分に取れば，PCの耐火性は 十分にあることが実験的に認められている。

(2) 火災事例

(a)PC 造の火災事例は、我が国では，土木で道路高架橋 の場合が見受けられるが，建築では見当たらない. (b)スウェーデンの工場 2 例が示されている.

第 1 例 : 火元に近い PC 柱は PC 鋼線の引張力の低下 は認められなかった。 PC 梁は火元に近い 2 本を除いて ほとんど被害がなかった。

第 2 例 : 火災修理後半年ぐらいでまた同じ場所で出火 し， 1 本の梁（ I 型断面）は，ウェッブが長さ $2.5 \mathrm{~m}$ にわ たって完全に抜けた。フランジは実際上ほとんど被害が なかった。 その後, 再び同場所より激しく出火したが, 構造的被害はほとんどなかった。

(c)厚さの薄いウェブ部分などでは火災によってコンク リートが抜けることもあるが，いずれも局所的な破損で あって，フランジ部分のように比較的厚い部分ではほと んど被害を受けず，修理後再使用が可能となる場合がほ とんどである。

(d)火災中のコンクリートの爆裂を防ぎ，かつ，火災中の 崩壊を防ぐためにも，部材の厚さはできるだけ大きくし ておくのがよい，部材厚さが $5 \mathrm{~cm}$ 以上であれば，爆裂の 危険性はほとんどない。

\section{$5 \cdot 1$ 川越らの研究}

\section{5 川越・齋藤の研究}

$5 \cdot 1 \cdot 1$ 床の耐火性 川越らは PC 床材の耐力および 耐火試験を報告している ${ }^{11)}$.

(1) 試験

試験は以下の条件で行った。

(a)加熱 : JIS A 1302 の耐火造 3 級（45 分）

(b)試験体 : 小ばり，床版

(c)コンクリート圧縮強度 : $500 \mathrm{~kg} / \mathrm{cm}^{2}\left(49 \mathrm{~N} / \mathrm{mm}^{2}\right)$

(d)鋼弦引張強度 : $18,000 \mathrm{~kg} / \mathrm{cm}^{2}\left(1,764 \mathrm{~N} / \mathrm{mm}^{2}\right)$

(2) 試験結果

以下の現象が観察された.

(a)試験開始数分以内で，爆裂が開始した。

(b)床版は爆裂破壊を起こし，小ばりも部分的に爆裂をし た.

従って, 細断面の PC 部材は耐火力が全くないと結論 ゔけている。 また，耐火的にするために、完全な耐火天 井を設けるなり, 絶対に剥落しない上狳り材を下面に塗 布するなりして十分な保護をする必要があるとしてい る.

$5 \cdot 1 \cdot 2$ 梁の耐火性 PC 梁の耐火試験を 3 種類実施 した ${ }^{12)}$. 1 つは，（1） PC 鋼棒梁の耐火試験であった. 試験条件は以下の通りであった.

(a)試験体 : 材長 $3.26 \mathrm{~m}$ ，せい $35 \mathrm{~cm} ， I$ 型断面梁

(b)コンクリート強度 : $459 \mathrm{~kg} / \mathrm{cm}^{2}\left(45 \mathrm{~N} / \mathrm{mm}^{2}\right)$

(c) $\phi 23.3 \mathrm{~mm}$ の高強度鋼 1 本を弓型に配置, $25 \operatorname{ton}(245 \mathrm{kN})$ のプレストレスカ導入

(d)加熱：JIS A 1302 の耐火 2 級（90 分）

(e)載荷 : 2 点荷重, $0.2 \operatorname{ton}(2.0 \mathrm{kN})$ と $2 \operatorname{ton}(19.6 \mathrm{kN})$ の 2 種 試験の結果，コンクリートの爆裂は 5 分から 10 分ま で生じ，ごく小規模であり，耐力に影響を与えるもので なかった。2ton $(19.6 \mathrm{kN})$ 載荷の場合, 冷却後, 目に見え る残留たわみがあり，底面に大きなき裂が残った。 
次に，（2） $\mathrm{T}$ 型梁の耐火試験，（3）ダブルティースラ ブ耐火試験を実施した。

上記の（1）から（3）までの試験結果より，以下のこ とが判明した。

(a)載荷、無載荷に関係なく，下端の鋼線温度が $350^{\circ} \mathrm{C} \sim$ $400^{\circ} \mathrm{C}$ を越える頃より，急にたわみが増加し，荷重が大 きい時は一気に折壊に至る。イギリスなどで許容温度を $400^{\circ} \mathrm{C}$ とている根拠である.

(b)ウエッブ幅 $12 \mathrm{~cm}$ あれば而火性能は 3 級 (45 分), $15 \mathrm{~cm}$ で 2 級（90 分）を確保できる.

\section{$5 \cdot 2$ 齋藤らの研究}

5・2・1 PC 部材の爆裂について 齋藤博士は PC 部材の爆裂について以下のように述べている ${ }^{13)}{ }^{14)}$.

PC 部材の火災時の性状はほぼ解明されてきた。しか し, PC 部材の爆裂の原因は充分に解明されていない. $\mathrm{PC}$ 部材の爆裂の原因は熱応力がその圧縮強度以上に成 長するためと考えられる (図 7 参照)。薄肉部材 (床版、 ルーバーなど）は爆裂によりコンクリートが抜け，完全 に部材の機能を失う。厚肉部材は爆裂による構造的崩壊 は生じないが，コンクリート表面の小部分が爆裂して飛 散する。

爆裂が生じやすい条件は前記 $3 \cdot 2$ 節（2）で述べた。 また，PC 部材の加熱時の爆裂はコンクリート内部の温 度分布に起因するものであるため, 耐火性を損なうこと なく爆裂を防止する方法としては，以下の方法が考えら れる。

(a)温度分布が急変せず，直線的になるようにする（耐火 被覆の付加).

(b)特殊骨材を用いてコンクリートの高温時の線膨張を 普通コンクリートより小さくする.
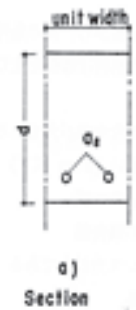
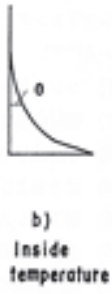

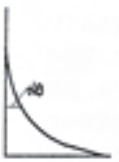

c) expotsion atit ored

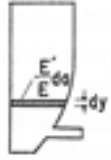

(d)
図 7 熱応力の解析 ${ }^{14)}$

5・2・2 FIP 報告 1966 年 6 月に第 5 回 PC 国際会 議（FIP） が開催された。本報告 ${ }^{15)}$ はPCの耐火性に関 する研究の国際的動向とその水準を示している. FIP は 火災時の信頼を深めるため, 最善を尽くすべきであると 述べた。以下のことが立証された。

(a)PC は RCよりも悪い性状を示さない.

(b)PC 部材は火災により破壊するとき, 直ちに明確な兆 候を示す.

(c)望む耐火性能は経済範囲で得ることができる.
Braunschweig の特別委員会（1 年前に開催）での主要 テーマは以下であった。

(a)伸び拘束，回転拘束

（b）爆裂，耐火被覆，プレストレスト形式の影響等の特 殊問題

(c)法規における耐火性の定義および経済問題

(d)実火災時の PC 部材の挙動と耐火試験結果の比較およ び今後の規準に対する要望

また, 特別委員会での今後の研究に対寸る要望は以下 であった。

(a)実験方法の統一と経験の交流

(b)鋼材およびコンクリートの高温時の性状

(c) PC 鋼材の「かぶり」の影響

(d)爆裂

(e)設計上の重要な原則

(f)実火災と而讨試験の比較

$5 \cdot 2 \cdot 3$ 火災時における PC 構造部材の内部温度上 昇の停滞について ${ }^{16)}$ 試験体は PC 鋼棒を中心に配した 正方形断面（200mm 角他）の部材（長さ： $2 \mathrm{~m}$ ）である

(図 8 参照). パラメーターは断面寸法、 Fc $\left(400 \mathrm{~kg} / \mathrm{cm}^{2}(39\right.$ $\left.\mathrm{N} / \mathrm{mm}^{2}\right)$ ) , プレストレス導入応力 $\left(40 \mathrm{~kg} / \mathrm{cm}^{2}\left(3.9 \mathrm{~N} / \mathrm{mm}^{2}\right)\right)$, 含水率（5\%）であり，（）内は目標值であった。

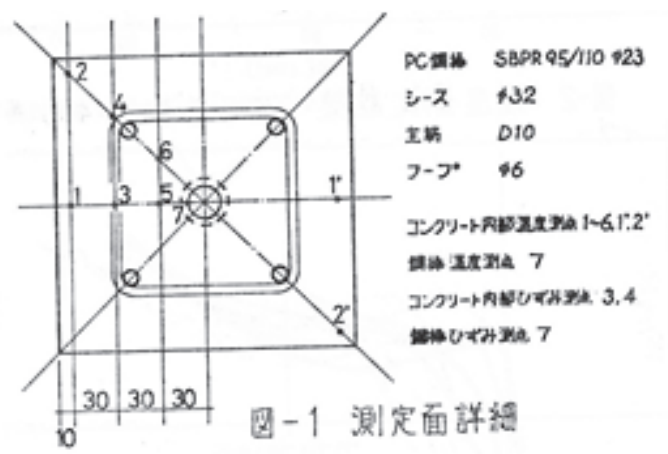

図 8 PC 構造部材の試験体 ${ }^{16)}$ (寸法単位 : mm)

以下の場合に停滞温度が高くなることが判明した。

(a)プレストレス導入忘力が小さいほど.

(b)加熱速度が緩やかなほど。

(c)断面が小さくなるほど.

$5 \cdot 2 \cdot 4 \quad P C$ ばりの加熱後の曲げ耐力 ${ }^{17)}$ 試験体仕様 は以下の通りであった。

(a)断面 : $200 \mathrm{~mm} \times 300 \mathrm{~mm}$

(b)PC 鋼棒 : 上下 2 本, $\phi 23 \mathrm{~mm} 、 \mathrm{~B}$ 種 1 号 $\mathrm{SBPR} 95 / 110$ (c)コンクリート : 強度 $357 \mathrm{~kg} / \mathrm{cm}^{2}\left(35 \mathrm{~N} / \mathrm{mm}^{2}\right)$

加熱は標準に対し，1、3/4、1/2の 3 水準として，加熱 後くり返し純曲げ 2 点載荷を実施した.

試験の結果は以下の通りであった。

(a)常温に対する耐力の低下は, 加熱時間が長くなるほど 大きい. 90 分加熱で 33\%低下した.

(b)加熱温度が高くなるほど, 耐力低下が大きい. 
$5 \cdot 2 \cdot 5$ 火災時における PC 構造の鋼棒のひずみ変 動について ${ }^{18)}$ 上記 $5 \cdot 2 \cdot 4$ 項と同じ試験体仕様で実験 を行った.PC鋼棒のひずみは加熱開始とともに増加し， 加熱終了で減少する.

上述の理由は，コンクリートが $\mathrm{PC}$ 鋼棒より先に温度 上昇して熱膨張し，その後、コンクリートの弾性係数の 低下が著しくなり，鋼棒自体も熱膨張寸るためである.

\section{5・2・6 火災時における PC ばりの内部応力解析 ${ }^{19)}$}

上記 $5 \cdot 2 \cdot 5$ 項の実験と熱応力解析 (非線形直接剛性法) を比較した結果，温度経過は良く一致した。 その他の結 果は，以下の通りである。

(a)PC 鋼棒のひずみ: 加熱開始約 20 分まで, 増加する (コ ンクリートの熱膨張による)。その後，ひずみは減少す る（内部温度上昇と表層コンクリートの圧壊による剛性 低下)。

(b)ひび割れ、圧壊 : PC 部材断面は導入により全面圧縮 となり，加熱開始後表層部の熱膨張により断面中心部に ひび割れが発生する．表層部の圧壊の進行に伴い再び閉 じる。加熱終了以後, 表層の温度効果によりひび割れが 発生する

(c)曲げ剛性の低下 : 加熱初期のひび割れに対応し，急激 に低下し，その後圧壊の進展に伴い初期剛性の $1 / 4$ まで 減少する

\section{6 建設業界の研究}

建設業界の研究についていくつか述べる．床に関する 研究が多く，ここでは，プレキャスト・繊維補強入りな どの PC 床の研究を記載する.

\section{6・1 プレキャスト PC 合成床版 ${ }^{20)}$}

JIS A 1304 の標準加熱で，1 時間，2 時間の載荷加熱試 験を実施した。

(1) 試験体 : スラブ相互の接合目地を含み, 現場打ち コンクリート部と PC 部から成り，リブ部補強仕様を実 験変数とした (図 9、図 10 参照).

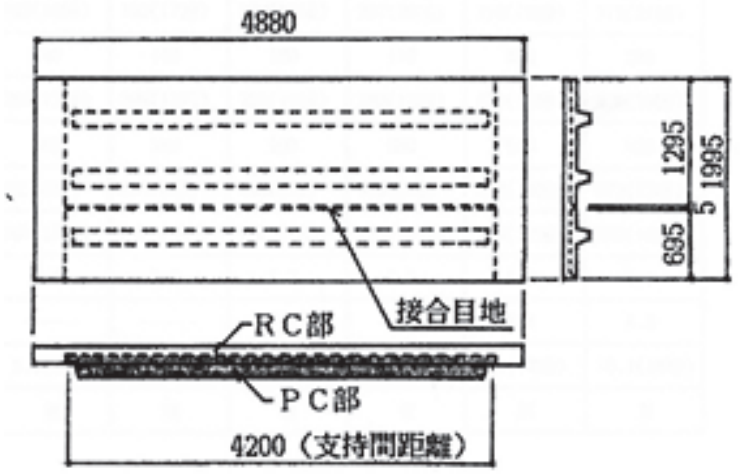

図 9 プレキャストPC 合成床版の試験体の形状 · 寸法 ${ }^{20)}$ (寸法単位：mm)

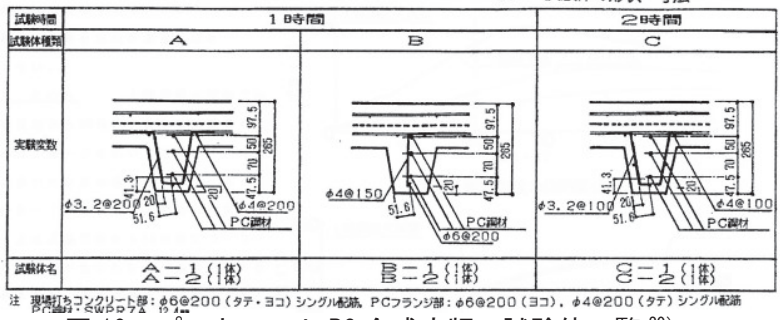

図 10 プレキャストPC 合成床版の試験体一覧 ${ }^{20}$

(寸法単位：mm)

（2）試験の結果，1 時間耐火は満足した（図 11、図 12 参照)。2 時間は一部裏面温度が規定值を超えた。現 場コンクリート部の厚さを厚くする必要がある。

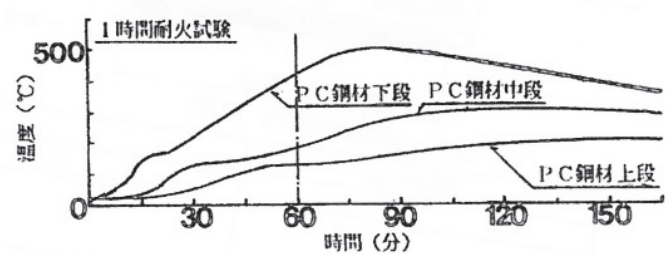

図 11 プレキャストPC 合成床版の鋼材温度の経時変化 ${ }^{20)}$

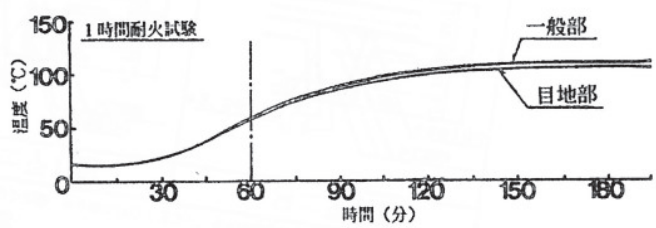

図 12 プレキャストPC 合成床版の裏面温度の経時変化 ${ }^{20)}$

\section{6・2 織維補強入り PC スラブ ${ }^{21), 22)}$}

超高強度繊維補強コンクリート材料を用いた PC スラ ブを図 13 および図 14 に示される土木構造物へ適用した。

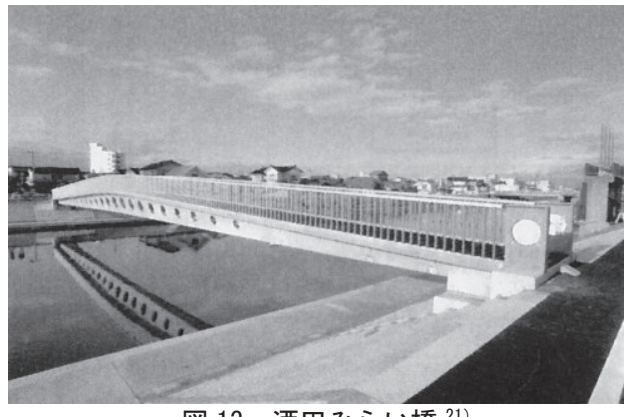

図 13 酒田みらい橋 ${ }^{21}$

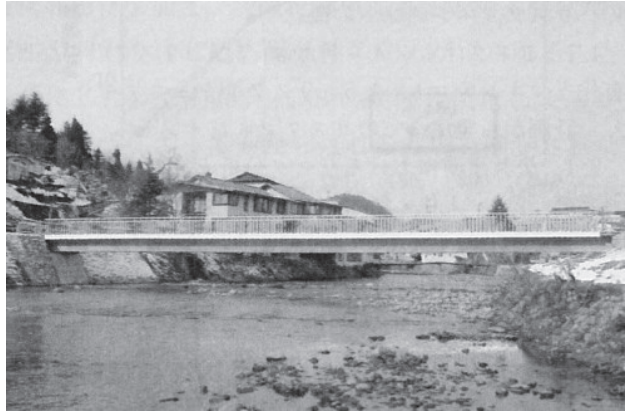

図 14 赤倉温泉中けむり橋 ${ }^{21}$ 
試験体仕様は以下の通りである（表 1 および図 15 参 照).

(1) 厚さ $90 \mathrm{~mm}$ の平板（A シリーズ）およびリブ断 面（リブ厚 $250 \mathrm{~mm}$ および $170 \mathrm{~mm}$ 、一般部 $70 \mathrm{~mm}$ ）（B シ リーズ) の 2 種

(2) プレテンション方式でプレストレス導入 加熱は片面および両面とした（図 16 参照）。 試験後, 表層のごく一部にはく離が認められたが, 形状 は保持していた（図 17 参照).

たわみ量は，加熱当初は片面加熱が大きいが，両面加 熱は断面内温度が早く高まり，曲げ剛性が低下し，急激 に増大した (図 18 及び図 19 参照)。加熱方法や断面形 状の相違によらず，引張鉄筋および緊張材の降伏強度を 評価することで，高温時の曲げ耐力の推定が可能である.

表 1 UFC スラブの実験の試験体 ${ }^{21) ， 22) ~}$

\begin{tabular}{|c|c|c|c|c|c|c|}
\hline 試雅名 & $\begin{array}{c}\text { 加熱 } \\
\text { 面 }\end{array}$ & $\begin{array}{c}\text { 遒入緊 } \\
\text { 張力 } \\
\mathrm{kN} \\
\end{array}$ & \begin{tabular}{|c|} 
中央位置での作用 \\
モーメント \\
$\mathrm{kN} \times \mathrm{m}$ \\
\end{tabular} & $\begin{array}{l}\text { 耐力 } \mathrm{Mu}^{*} \\
\text { (計算値) } \\
\mathrm{kN} \times \mathrm{m}\end{array}$ & \begin{tabular}{|c|} 
作用荷 \\
重比 \\
$\mathrm{M} / \mathrm{Mu}$ \\
\end{tabular} & $\begin{array}{l}\text { 压絔強度 } \\
\mathrm{N} / \mathrm{mm}^{2}\end{array}$ \\
\hline$A-1$ & \multirow{4}{*}{ 上下 } & \multirow[t]{3}{*}{672} & 26.2 & \multirow[t]{3}{*}{42.6} & 0.62 & 197 \\
\hline$A-2$ & & & 18.5 & & 0.43 & 187 \\
\hline $\mathrm{A}-3$ & & & 13.1 & & 0.31 & 202 \\
\hline B-1 & & \multirow[t]{2}{*}{567} & \multirow[t]{2}{*}{24.3} & \multirow[t]{2}{*}{89.9} & \multirow[t]{2}{*}{0.27} & 195 \\
\hline B-2 & 下 & & & & & 176 \\
\hline
\end{tabular}

* $\mathrm{Mu}=\Sigma 0.9 \cdot$ at $\cdot \sigma \mathrm{y} \cdot \mathrm{d}$ として評価

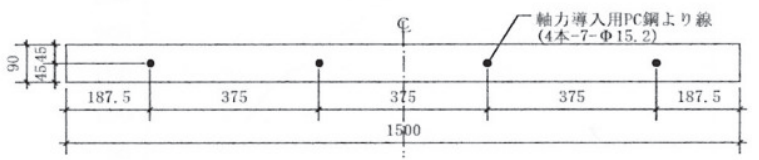

$A-1 \sim A-3$ 試験体

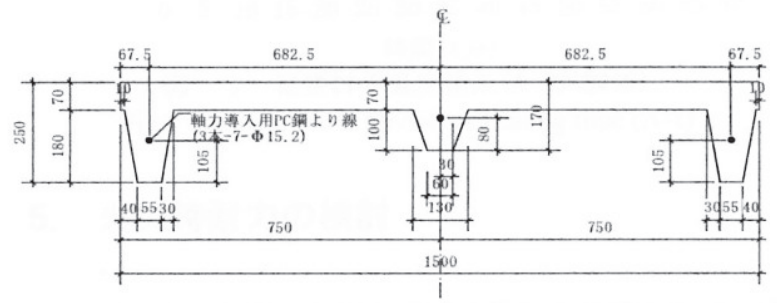

B-1 B-2試験体

図 15 UFC スラブの試験体断面形状 21)，22）（寸法単位：mm）

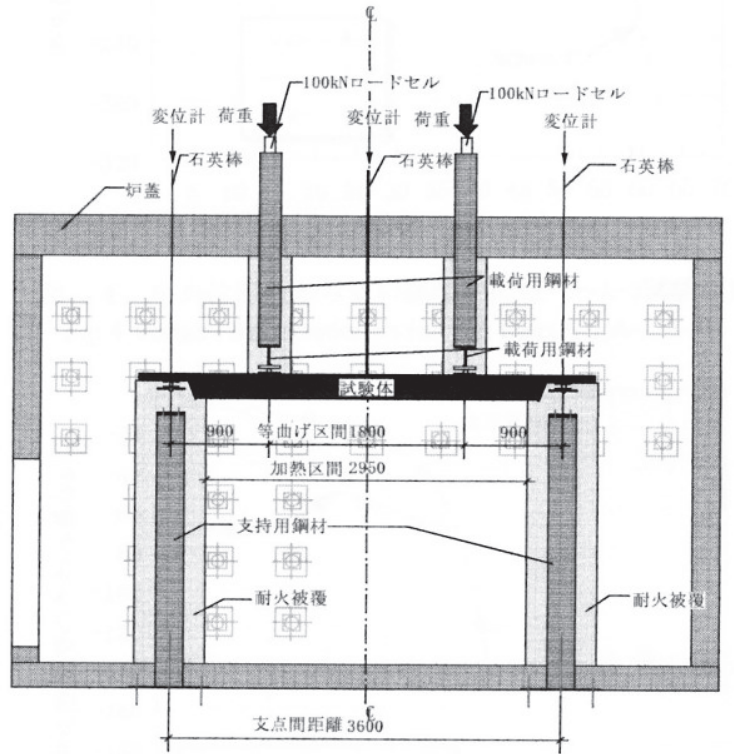

上下面加熱

図 $16 \mathrm{UFC}$ スラブの載荷加熱方法 21)，22）（寸法単位：mm）

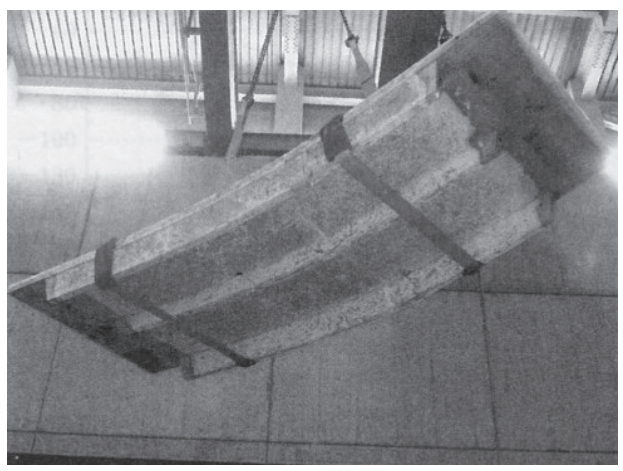

図 17 UFC スラブの実験後の試験体状況 21)，22)

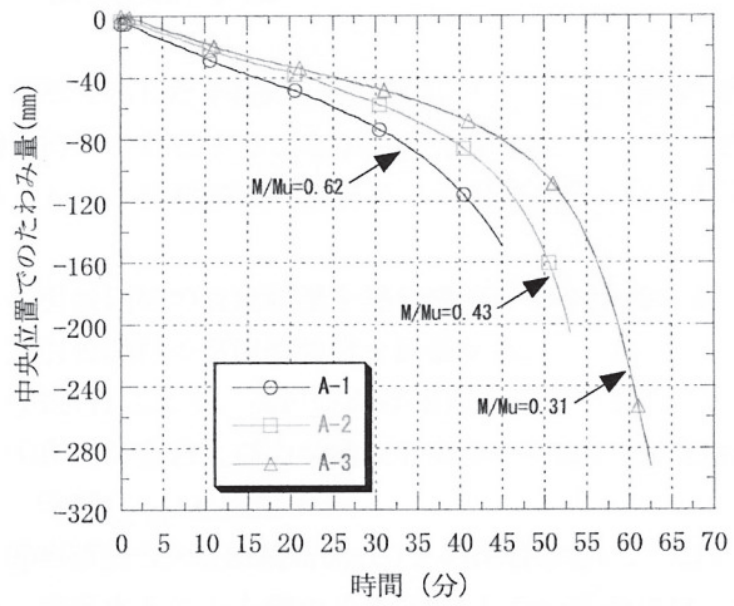

図 18 UFC スラブの中央位置たわみ量の経時変化 (A シリーズ) 21),22) 


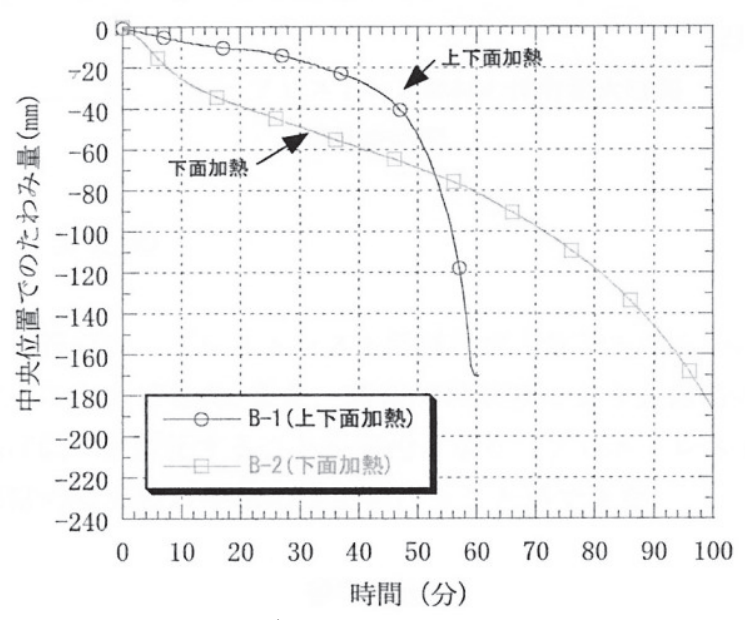

図 19 UFC スラブの中央位置たわみ量の経時変化 (B シリーズ) 21)，22)

\section{7 西山研の研究}

性能評価型設計法構築の一環として，PC 部材の火災 条件下の荷重〜変位特性を検証している。西山博士らの 研究は以下の 3 項目を重点的に検証している.

(1)高温下における PC 鋼材のクリープ特性やリラクゼ ーション特性の把握

(2) ISO 規準による火災条件下のPC 梁のたわみ特性の 把握

(3)火災後の梁の残留たわみと耐荷重性能の把握

以下に最近の研究内容を紹介寸る.

\section{$7 ・ 1 \quad P C$ 鋼棒の高温時の特性}

$7 \cdot 1 \cdot 1 \quad P C$ 鋼棒の高温下における引張試験 鋼材 として SB1 $(\phi 13 \mathrm{~mm}), \operatorname{SB} 2(\phi 9.2 \mathrm{~mm})$ の 2 種類を用 い，常温， $100^{\circ} \mathrm{C}$ か $600^{\circ} \mathrm{C}$ まで $100^{\circ} \mathrm{C}$ ピッチの一定温度 下で応力ーひずみ曲線を求めた ${ }^{23)}$. その結果, 以下のこ とが判明した。

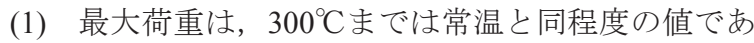
るが，300² 超えると急激に低下する。

(2) 弾性係数は, $200^{\circ} \mathrm{C} て ゙$ 常温時とほぼ同程度, $400^{\circ} \mathrm{C}$ 超えると急激に低下寸る。

(3) 降伏強度は，EUROCODE や鋼構造而讨設計指針 の提案式より低い值であった。

7・1・2 PC ストランドの高温時の特性 鋼材とし て, $\phi 12.7 \mathrm{~mm}$ の $\mathrm{PC}$ ストランドを用い, 常温, $100^{\circ} \mathrm{C}$ ら $600^{\circ} \mathrm{C}$ まで $100^{\circ} \mathrm{C}$ ピッチの一定温度下での最大強度, および常温, $100^{\circ} \mathrm{C}, 200^{\circ} \mathrm{C}, 300^{\circ} \mathrm{C}$ での応力ーひずみ曲 線を求めた ${ }^{24)}$. その結果，以下のことが判明した。

（1）引張強度 : $200^{\circ} \mathrm{C}$ までの強度低下はほとんどない が，それ以降は温度に比例して急激に低下寸る。

(2) 応力ーひずみ関数 : $0.4 \%$ 付近までは, 温度に関係 なくほぼ同じ挙動を示した。 $0.4 \%$ よりきなひずみでは, 温度の上昇とともに早期に剛性低下が見られた。

(3) ヤング係数 : $300^{\circ} \mathrm{C}$ までの範囲では，温度にかか わらずほぼ一定で，PC ストランドとその他の鋼材の間 に大きな違いは見られなかった。温度が上昇すると低い 温度で軟化が始まる。

\section{$7 ・ 2 \quad P C$ 梁の高温時曲げ耐力}

$\mathrm{PC}$ 梁部材の高温時曲げ耐力を評価した ${ }^{25)}$.

(1) 目的は PC 部材の火災時曲げ耐力評価を行うため の基礎研究であり, 以下に主な研究内容を示す.

(a)PC 鋼材の高温時特性について, 既往の研究，著者ら の実験に基づきモデル化する.

(b)熱伝導の簡易式を用い, 部材断面内温度分布から, PC 部材の火災時曲げ耐力を算定する。

(c) 火災時に対して PC 規準で示されている PC 鋼材かぶ り厚さの妥当性を検証する.

(2) 火災耐力に対する PC 部材特有の以下の問題を提 起した.

(a)高温レラクゼーションと鋼材の強度低下により鋼材 が破断した.

(b)プレテンション部材では, 鋼材とコンクリートの付着 の減退によりプレストレスカの喪失により常時荷重の 支持が不能となる. せん断力低下によるせん断破壊へも 繋がる.

(c)PC 鋼材の高温時の強度低下が大きい.

(3) 結果

以下のことが判明した。

(a)PC 鋼材の高温時の耐力低下をモデル化し，梁断面の 温度分布を略算により評価する方法を提案した. 90 分, 120 分で Euro Code 2 に比べ過小評価であり, 隅各部や側 面上方でやや高めの温度を示し, さらに改善する必要が ある。

(b)PC 梁の高温下での曲げ強度評価法を提案した. PC 規 準 ${ }^{2)}$ の鋼材かぶり厚さは, 本提案に比し, 床 2 時間はや や小さいが，柱や梁は逆に大きい.

(c)骨組中の両端固定梁を想定すれば, 火災により梁中央 部での曲げ耐力喪失でも常時荷重は支持できる.

\section{7・3 PC 梁の高温時の力学性状}

$\mathrm{PC}$ 梁の高温時力学性状について実験的研究を行った 26) ,27)

(1) 目的

単純支持 PC 梁の耐火試験を行い，火災時および火災 後の挙動 (内部温度变化、剛性、残存強度) を把握する。

(2) 試験体

断面は $250 \times 350 \mathrm{~mm}, \quad \mathrm{PC}$ 鋼材 $\phi 21 \mathrm{~mm}$ (C 種 1 号）を 上縁から $150 \mathrm{~mm}, 262.5 \mathrm{~mm}$ の位置に 1 本ずつ配置してい る. パラメーターとしては，加熱時間 30 分， 60 分の 2 種類である。

(3) 実験結果

以下のことが判明した。

(a)図 20 に試験体の試験中および試験後の状況を示す.

(b)内部温度変化: 加熱終了時の $\mathrm{PC}$ 鋼材温度は PC 規準 ${ }^{2)}$ の許容平均鋼材温度 $450^{\circ} \mathrm{C}$ 以下であった。

(c)たわみ変化: 加熱開始後 20 分まで急激に増大, その 後緩やかに増大し, 160 分以降急激に増大寸る.

(d) 剛性 : 30 分加熱終了時で 68.3\%, 60 分加熱終了時に $51.3 \%$ に低下した。 
(e)PC 鋼棒張力 : 加熱 160 分まではほぼ一定, その後低 下した。

(f)修復性の検討を行った。

(g)残存耐力：計算值の $74.6 \%$ よび $93.5 \%$ となった.

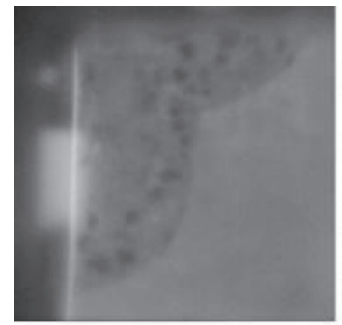

Concrete in $1,200^{\circ} \mathrm{C}$ condition

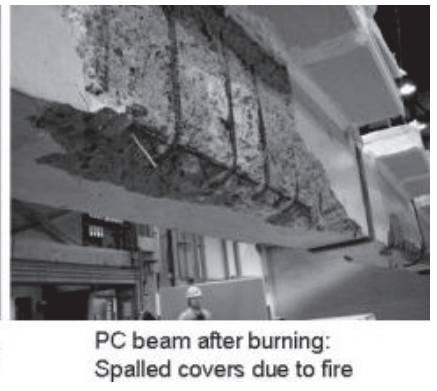

図 $20 \mathrm{PC}$ 梁の耐火試験中および試験後の試験体の状況

\section{8 海外の研究}

\section{$8 \cdot 1$ ACI}

ACI では, Troxell が PC 床パネルの 4 時間耐火試験 の報告をしている ${ }^{28)}$.

(1) 試験条件

(a)試験体寸法: 大きさ $16 \mathrm{ft}(487.7 \mathrm{~cm}) \times 16 \mathrm{ft}(487.7 \mathrm{~cm})$, 厚さ $6 \mathrm{in}(15.24 \mathrm{~cm})$

(b)ポストテンション方式でグラウトなし.

(c)設計荷重 : $75 \mathrm{psf}\left(3.6 \mathrm{kN} / \mathrm{m}^{2}\right)$

(2) 試験の結果

以下のことが判明した。

(a) 4 時間に耐え，縁はりおよび補剛はりに一部コンクリ ートのはく離が認められた。

(b)大変形が認められず, 冷却後のたわみの回復が著しい. (c)緊張材温度はかぶり厚さ $1.5 \mathrm{inch}(3.8 \mathrm{~cm})$ で，942 $\mathrm{F}\left(506^{\circ} \mathrm{C}\right)$ に達したが，力学的性質の低下による影響は 極めて少なかった。

\section{8 - 2 IABSE (International Association for Bridge} and Structural Engineering)

Gustaferro は火災時の PC 部材の挙動を計算により推 定した ${ }^{29)}$. 部材内の温度履歴と高温時のコンクリートと 鋼材の物性值を用いた。火災時のはりや床版の熱膨張の 拘束を扱った計算例がそしく，熱膨張力を考慮した。

（1）単純支持の場合は, 鋼材およびコンクリートの高 温時の強度を用い，常温時の式を利用して，計算可能で ある。

（2）連続支持の部材の熱変形は，作用曲げモーメント の再配分により生じる.

\section{9 土木分野における研究}

土木分野での研究を以下に概括する.

9・1 けた

PC 林の火災実験を行った ${ }^{30)}$.

(1) 試験けた

(a) 寸法 : 長さ $13 \mathrm{~m}$ ，高さ $1 \mathrm{~m}$ の T型断面

(b)PVC 鋼線 : $12 \times \phi 7$ のフレシネケーブル (c)コンクリート: 圧縮強度 $426 \mathrm{~kg} / \mathrm{cm}^{2}\left(42 \mathrm{~N} / \mathrm{mm}^{2}\right)$ (4 週) (2) 試験方法

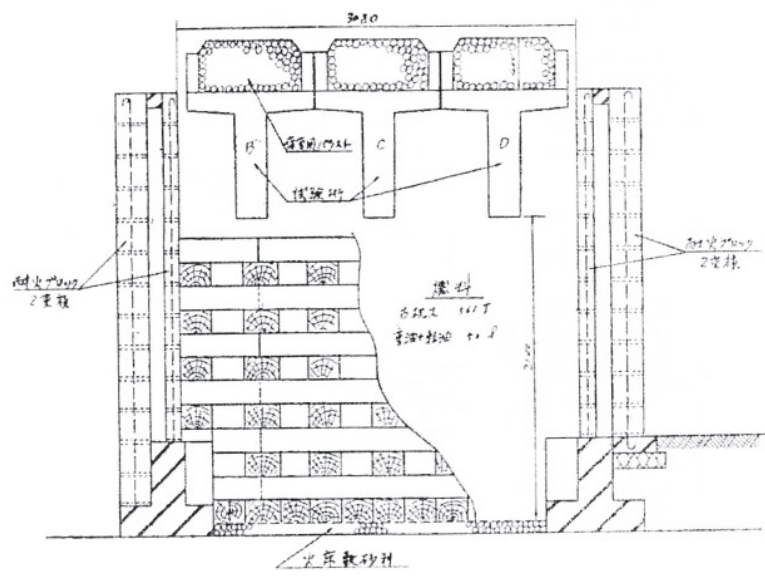

図 $21 P C$ けたの加熱試験装置 30)

2 時間の JIS A 1302 標準加熱試験を実施した（図 21 参照).

（3） 試験結果

以下のことが判明した。

(a)爆裂はなかった。

（b)かぶり $4 \mathrm{~cm}$ 以上あれば，冷却後の $\mathrm{PC}$ 鋼線の強度低 下はほとんどない。ばらつきを考慮すると， $5 \mathrm{~cm}$ 以上が 望ましい。

(c)2 時間 10 分の加熱で，ひびわれ抵抗が $34 〜 56 \%$ ，曲 げ破壊抵抗が 47〜 66\%に低下した。

(d)有効な防護施工（厚さ $2 \mathrm{~cm}$ のパーライトモルタル） をすれば，耐火性は 1 時間延長される.

\section{$9 \cdot 2$ 橋}

火害を受けた高架橋の補修調査および工事を行った 31),32).

（1）対象 : 橋長 $124 \mathrm{~m}$ の 3 径間および 2 径間の連続 $\mathrm{PC}$ 中空床版橋，幅員 $9.5 \mathrm{~m}$

（2）現地調査（外観、圧縮強度、受熱温度推定）の結 果, コンクリートの剥落は最大 $40 \mathrm{~mm}$, 圧縮強度や弾性 係数は低下し, 受熱温度は表面から $70 \mathrm{~mm}$ の位置で約 $200^{\circ} \mathrm{C}$ であった。

（3）耐荷力照査の結果，上部工は許容応力度を満足す る.

（4）実橋載荷試験は大型ダンプを 4 台用い, 支間中央 に載荷した。 その結果, 耐荷性能は十分に保持される. 損傷した脆弱部をはつり取り (図 22 参照), 断面修復し た. 


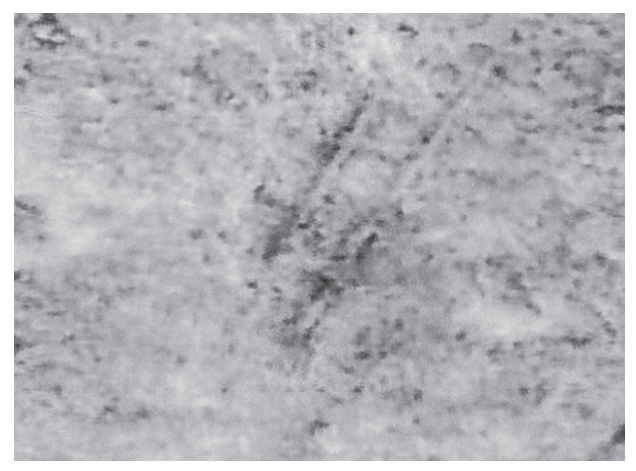

図 $22 \mathrm{PC}$ 床版橋の鉄筋の露出状況 ${ }^{32)}$

\section{$9 \cdot 3$ 梁}

江戸橋自動車駐車場の大型断面を持つ PC 梁について 実験を行った ${ }^{33)}$ (図 23 参照)。JIS A 1304 の 2 級耐火 試験（120 分）に合格した（図 24 参照)。ただし，小規 模な爆裂は生じる可能性がある.

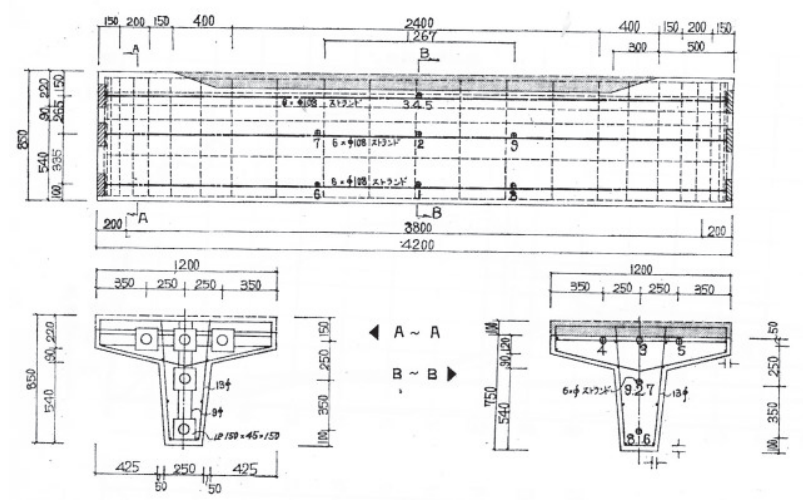

図 $23 \mathrm{PC}$ 梁の試験体 ${ }^{33}$
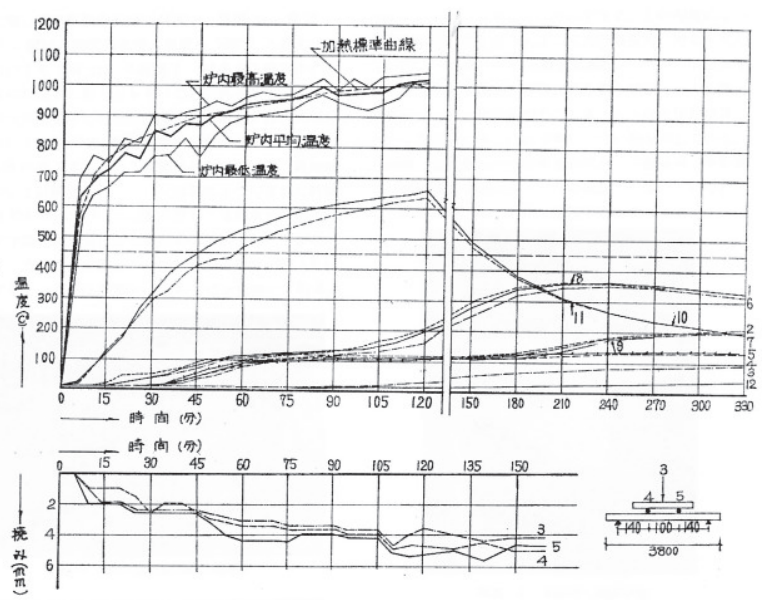

図 24 PC 梁の耐火試験結果（温度およびたわみ） ${ }^{33)}$

試験の結果，火災を受けた後の強度低下は約 $15 \%$, 剛 性低下は約 $1 / 5$ であった。局部的な補修により再使用可 能である。

\section{$9 \cdot 4$ パイル}

鋼管被覆 PC パイルを建築構造部材に使用する場合の 耐火性を調べた ${ }^{34)}$. 鋼管複合高強度コンクリートパイル
と鋼管被覆のない $\mathrm{PC}$ パイル（遠心力利用工業製品のプ レストレスト高強度コンクリートパイル）とを比較した (図 25 参照).

(1) 目的

(a)耐火被覆を施すことにより, 火災後の再使用可能性を 検討する。

(b)低層建築物の柱への利用を検討する.

（2）試験結果（図 26 参照）より，以下のことが推論さ れる。

(a)PCパイル:ロックウール被覆は耐火 1 時間で $10 \mathrm{~mm}$, 2 時間で $15 \mathrm{~mm}$ 必要.

(b)現場打ちポストテンション方式 PC 部材 :

1）圧縮強度 $500 \sim 600 \mathrm{kgf} / \mathrm{cm}^{2}\left(49 \sim 59 \mathrm{~N} / \mathrm{mm}^{2}\right)$ で，ロック ウール被覆厚さは耐火 1 時間で 10〜 $15 \mathrm{~mm} ， 2$ 時間で 15 20mm 必要.

2）圧縮強度 $400 \sim 500 \mathrm{kgf} / \mathrm{cm}^{2}\left(39 \sim 49 \mathrm{~N} / \mathrm{mm}^{2}\right)$ で，ロック ウール被覆厚さは耐火 1 時間で 15〜20mm，2 時間で 20〜25mm 必要.

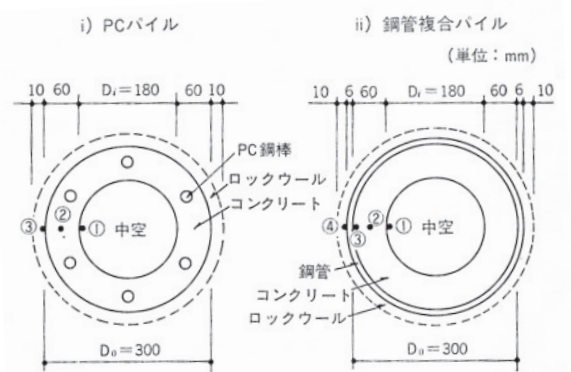

図 25 パイルの試験体 ${ }^{34)}$

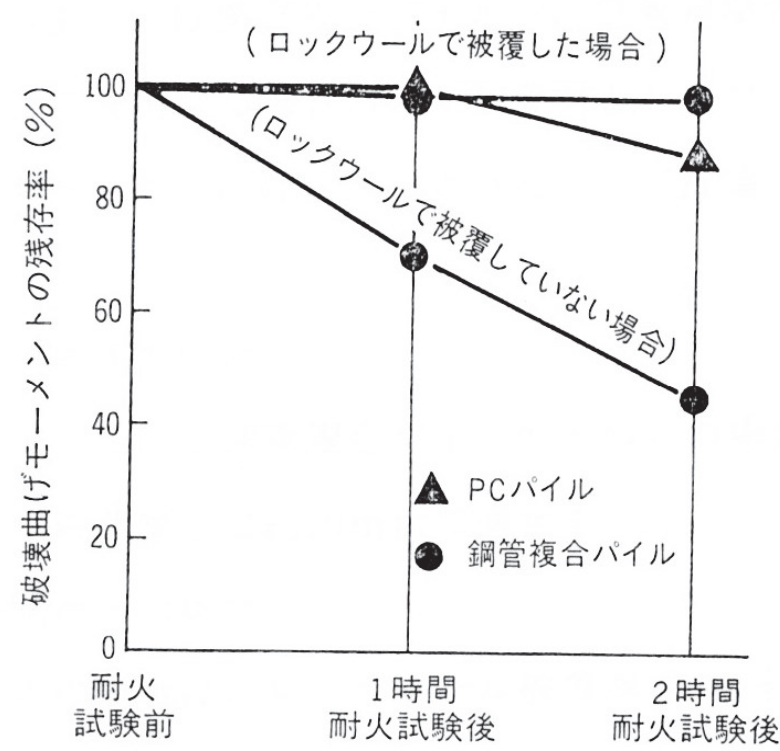

図 26 パイルの破壊曲げモーメントの残存率 ${ }^{34}$ 


\section{$9 \cdot 5$ スラブ}

PC スラブの RABT 火災曲線による耐火試験を行った ${ }^{35)}$. （1）供試体（図 27 参照）

(a) 寸法 : 幅 $500 \mathrm{~mm}$, 高さ $300 \mathrm{~mm}$, 長さ $2000 \mathrm{~mm}$

(b) PC 鋼より線 : 上・下面 2 本ずつ

(c) コンクリートの圧縮強度 : $53.5 \mathrm{~N} / \mathrm{mm}^{2}$

(d) 加熱面を厚さ $15 \mathrm{~mm}$ の湿式吹き付けを施す.

(2) 試験方法

（a）載荷：荷重 $100 \mathrm{kN} 、 3$ 等分 2 点載荷

(b) 加熱 : RABT 60 (5 分で $1200^{\circ} \mathrm{C} 、 1200^{\circ} \mathrm{C}$ を 55 分保持)

(c) 加熱面 : 下面 $600 \mathrm{~mm}$ の区間

(3) 試験結果

以下のことが判明した (図 28 参照).

(a)試験中は大きくたわむ.

(b) 受熱部のコンクリートの剛性低下により, 試験後た わみの増加，中立軸の上昇が見られた。

(c) 試験後は下部コンクリートの剛性低下により，上反 りに変形した.

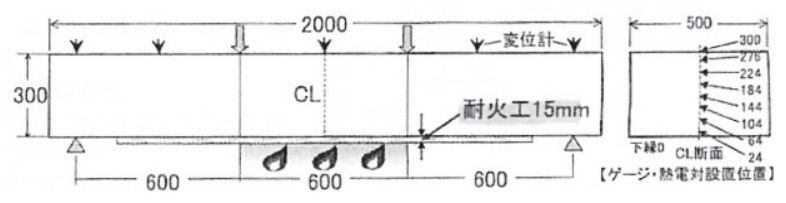

図 27 PC スラブ供試体と断面内ひずみ一温度測定点概要 ${ }^{35)}$ (寸法単位：mm)

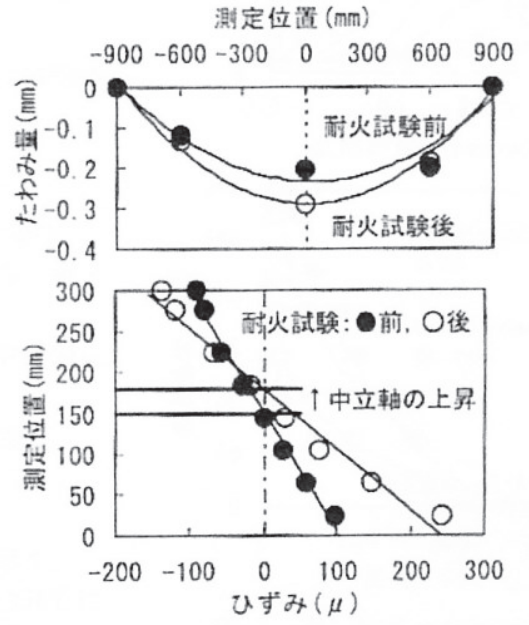

図 28 耐火試験前後の $100 \mathrm{kN}$ 載荷によるスラブの たわみとひずみ ${ }^{35)}$

\section{0 結}

言

PC 構造の耐火性に関する研究の動向について述心゙, 以下のことが判明した。

(1) PC 部材の火災時の性状はほぼ解明されている とも言われている.

(2) PC 構造は適切な処置を施せば，耐火性は十分に 確保されることが分かった。
(3) 耐火的に有利な条件を具備すれば, PC 部材は RC 部材に比心゙，悪い性状を示さない.

（4） PC 部材のコンクリートの爆裂が生じや寸い条件 が示された。

(5) 爆裂の原因は充分に解明されていない.

（6）爆裂を防止する方法が示された.

（7）火災後、再使用を考慮するのであれば，耐火被覆 が必要である。

(8) PC 部材の高温時の曲げ耐力評価法が提案されて いる ${ }^{25)}$.

（9） PC 構造の火災事例はほとんど見当たらない。火 災があっても被害はほとんどなく, 再使用可能なものが ほとんどである。

(10) PC 構造は耐火性に配慮した上で, その構造上の 特長を充分に活かし，多用されることが望まれる.

今後の検討課題としては, 以下のことが主に挙げられ る。

（1）各種火災を想定した加熱方法（急速加熱（RABT 曲線）、緩慢加熱（slow heating）等）の検討.

(2) 爆裂対策の検討（䋊維混入など）.

(3) PC 部材の火災時の適切な耐力評価法の開発.

(4) 各種接合部の性能の把握.

(5) $\mathrm{PC}$ 構造の火害診断とその補修・補強方法の検討.

1) The Ministry of Construction (Ministry of Land, Infrastructure, Transport and Tourism) "The matter establishing method of structure of fire-resisting construction", No.1399 of the public notice of the Ministry of Construction(2000).

2) AIJ "Prestressed concrete design construction standard and this explanation", pp.463-473(1998).

3) The Revised Building Standards Law of Japan (2000).

4) General Building Research Corporation of Japan "The method book of fire-proof performance test and evaluation" (2005).

5) Prestressed Concrete Engineering Association "Design and construction guidance for holed PC board", pp.127-128(1978).

6) AIJ "Guide book of fire-resistance of structural materials", pp.166-171(2009).

7) Japanese Society of Steel Construction "Mechanical properties of steel bar, PC bar and wire at high temperature and after heating", JSSC, Vol.5, No.45, pp.1-62(1969).

8) Japan Association for Fire Science and Engineering "Fire prevention teaching materials", pp.90-96(1980).

9) S.Ban "Fire-resistance of PC frame members", Journal of architecture and building science (1956).

10) H. Muguruma "1.5 Fire-resistance of prestressed 
concrete", PC, Architectural, structural course, Vol.8, pp.12-17(1969).

11) K. Takeyama, S. Takenouchi and K. Kawagoe "Examination report of bearing force and fireproof of prestressed concrete floor members", The 1st bridge and structure engineering research presentation meeting, pp.105-110(1954).

12) K. Kawagoe "Fire resistance test on prestressed concrete beam", The 6th bridge and structure engineering research presentation meeting, pp.187-196(1959).

13) H. Saitou "Fireproof of prestressed concrete", KASAI, pp.23-30(1996).

14) H. Saitou "About the explosion of the prestressed concrete members", AIJ thesis report collection extra, p.688(1966).

15) H. Saitou "Fireproof of prestressed concrete (the 5th FIP international conference and committee report)", KASAI, pp.25-30(1967).

16) H. Saitou, H. Uesugi, H. Ishikawa and H. Saito "About the stagnation of the internal temperature rise of prestressed concrete structural members in fire", Summaries of technical papers of annual meeting AIJ, pp.1821-1822(1979).

17) H. Saitou,H. Uesugi, H. Saito, and K. Ikeda "The bend bearing force after heating of prestressed concrete beams", Summaries of technical papers of annual meeting AIJ, pp.2401-2402(1981).

18) H. Saitou, H. Uesugi, H. Saito and K .Ikeda "About the strain change of steel bar of the prestressed concrete structure in fire(2nd)" Summaries of technical papers of annual meeting AIJ, pp.2403-2404(1981).

19) H. Ohashi, T. Ota, H. Uesugi and H. Saitou "Internal stress analysis of prestressed concrete beams in fire", Summaries of technical papers of annual meeting AIJ, pp.2487-2888(1984).

20) M. Seno, S. Takeda, M. Komura and T. Someya "Fire-resistance of pre-cast prestressed concrete composite floors", Summaries of technical papers of annual meeting AIJ , pp.1025-1026(1990).

21) S. Baba, H. Sasai, H. Morita and K. Nozaki "Fireproof design of prestressed slab using super-high strength fiber reinforced concrete", Concrete engineering, Vol.45, No.7, pp.38-45( 2007).

22) S. Baba, S. Mitikoshi, Y. Kobayashi "Fire-resistance of prestressed slab using super-high strength fiber reinforced concrete", Summaries of technical papers of annual meeting AIJ , pp.75-76(2007).

23) K. Ito, T. Fukano, M. Nishiyama and K. Harada "Tensile test of PC bars under high temperature", Summaries of technical papers of annual meeting AIJ , pp.49-50(2005).

24) M. Hayashi, M. Tani, M. Nishiyama and K. Harada "Tensile test of PC strands under high temperatures", Summaries of technical papers of annual meeting AIJ , pp.837-838(2007).

25) M. Nishiyama, K. Harada and M. Tani "Bending force evaluation of prestressed concrete beams at high temperatures", Journal of structural engineering(Transactions of AIJ), No.606, pp.171-178(2006).

26) S. Im, Y. Furusawa, M. Tani, K. Harada and M. Nishiyama "Experimental research about structural property of prestressed concrete beam at high temperature (1st the experiment outline and experiment result outlines)", Summaries of technical papers of annual meeting AIJ , pp.913-914(2008).

27) S. Im, Y. Furusawa, M. Tani, K. Harada and M. Nishiyama "Experimental research about structural property of prestressed concrete beams at high temperature (2nd experimental results and consideration)", Summaries of technical papers of annual meeting AIJ , pp.915-916(2008).

28) G. E. Troxell "Fire resistance of a prestressed concrete floor panel”, Journal of ACI,Vol.31,No.2(1959).

29) A. H. Gustaferro "Design of reinforced and prestressed concrete structures for fire resistance", International Association for Bridge and Structural Engineering, pp.141-145(1976).

30) I. Nisugi, M. Sugawara and I. Noguchi "Fire experiments of prestressed concrete beams", JSCE(1959).

31) Y. Fujioka, Y. Kawauchi, M. Hisakado and K. Ishida "Repair investigation of fire-damaged viaduct", 58th annual academic meeting of JSCE, pp.433-434(2003).

32) Y. Fujioka, K. Ishida and T. Sonoda "Repair construction in fire-damaged viaduct", 58th annual academic meeting of JSCE , pp.435-436(2003).

33) Y. Yamamoto, S .Kobayashi and S. Sawai "About the design plan of Edo bridge car parking lot, (chiefly about fireproof of prestressed concrete structure)", Journal of structural engineering(Transactions of AIJ), pp.241-244(1961).

34) T. Oshima "Fireproof when steel pipe coating PC pile is used for building structural members", Cement \& Concrete", No.424, pp.8-16(1982).

35) A. Matsui, S. Nakamura, Y. Hamada and S. Tamura "Fire resistance test by RABT fire curve of PC slab", 59th annual academic meeting of JSCE, pp.967-968(2004). 